\title{
Sociology and History: contained dialogues
}

\author{
Sandro Serpa1 \& Carlos Miguel Ferreira2 \\ 1 University of the Azores, Faculty of Social and Human Sciences, Department of Sociology; \\ Interdisciplinary Centre of Social Sciences - CICS.UAc/CICS.NOVA.UAc; Interdisciplinary Centre for \\ Childhood and Adolescence - NICA - Uac, Ponta Delgada, Portugal \\ 2 Interdisciplinary Centre of Social Sciences - CICS.NOVA, Lisbon; ISCTE - University Institute of \\ Lisbon
}

Correspondence: Sandro Serpa, Department of Sociology, Faculty of Social and Human Sciences, University of the Azores, Rua da Mãe de Deus 9501-801 Ponta Delgada, Azores, Portugal. E-mail: sandro.nf.serpa@uac.pt

\begin{abstract}
Sociology and History as consolidated scientific and academic projects have maintained a peculiar and paradoxical relationship. The growing disciplinary and subdisciplinary specialization of these two sciences poses relevant epistemological and methodological challenges to face potential situations of isolation, fragmentation and enable the apology of an interdisciplinary perspective characterized by the historicity of social structures, actions and senses.

Several types of reasons shape this diffuse process of approach/distinction between Sociology and History, namely, epistemological and methodological, disciplinary closure, academic, professional, configuring what can be called contained dialogues. This paper, starting from the sociological perspective of the authors, seeks to contribute to the reflection on the relevance of a scientific project aimed at affirming an interdisciplinary perspective that may foster the heuristic potentialities of both Sociology and History in the analysis of the complexity of social reality and human action.
\end{abstract}

Keywords: Sociology, History, interdisciplinary dialogue 


\section{Introduction}

In several discursive records produced, at the end of the previous century, by authors who are located in different disciplinary spaces of the social sciences, namely, Silva and Pinto (1986) affirms a position that holds that all social sciences should also be historical, because "aware that societies are installed in change, of the multiplicity of social times, attentive to the irreversibility and uniqueness of facts and the historical thickness of social structures" (p. 24). This is the starting point of this essay, an old challenge that (as we shall see) has not yet been achieved (Baechler, 1990; Charry Joya, 2017; Steinmetz, 2017).

The relationship between Sociology and History, as fully-fledged scientific disciplines (Ferreira \& Serpa, 2017), has been a very present subject, at least since the formation of Sociology, having suffered several expressions over time (Do Valle, 2014; Charry Joya, 2017; Gould, 2019; Torres, 2012; Steinmetz, 2017). According to Zubiría (2015), these different expressions show different paths, which can be traversed and analyzed as parallel or juxtaposed paths. However, in the opinion of Zubiría (2015), the approach that seems most appropriate and faithful to the truth is its analysis based on a dialectical perspective, which allows the concomitant presence of the convergent and the divergent. Sociology and History - allied sister and simultaneously rival (Javeau, 1998). Already in the year 2019, Malczewski considers that:

"Contemporary sociology's aloof posture towards general theory is compounded by the discipline's growing tendency to produce studies of micro- and meso-level phenomena with a presentist or short-term orientation. The presumption of such studies appears to be that the effective forces of human society or the constitutive qualities of historical phenomena can be grasped in data that take the standpoint of the present or that concern short time horizons (...) Without keeping one eye on what is constant and regular sociology cannot clearly identify what is contingent and fluid" (p. 12).

Sociology's assertion as a science has privileged the affirmation of its theoretical plurality, which seeks to articulate macro-social dynamics with local processes, allowing for the connection between subjective meanings and practices, and which focus on the articulations between systems and actors, between structures and practices, between the reality of social conditions of existence and the social construction of reality (Dubar, 2006; Sethuraju, Prew, Abdi, \& Pipkins, 2013; 
Morrison, 2017; Ferguson, 2016).

History can be defined as the study of human societies, with an emphasis on the differences between them and the changes over time in each one (Burke, 1980). However, as Braudel reiterates, History privileges in social reality analysis a perspective that emphasizes social duration "those multiple and contradictory times in men's lives that are not only the substance of the past, but also the matter of current social life" (Braudel, 1958b, p. 9).

In order to overcome some of the limitations of the increasing disciplinary and subdisciplinary specialisation, fragmentation and isolation of these sciences, a strategy of rapprochement between these and other scientific disciplines may be preferred: multi-inter-transdisciplinarity, concepts that sometimes appear to be used in a similar way to each other (Barthel, \& Seidl, 2017), despite their subtle differences (Stock, \& Burton, 2011) even within the concept of interdisciplinarity itself (Razmak, \& Bélanger, 2016). In a synthetic way, there is a difference in the degree of deepening, but not only, in the practical application of these three concepts. Multidisciplinarity "has a clear purpose of joint problem solving by involving different disciplines. However, individual disciplines can work on different aspects of a problem in parallel. Multidisciplinary research is more often temporary, limited to a specific project or problem than interdisciplinary research; interdisciplinarity "entails the most intense collaboration, involving the dissolution of disciplinary boundaries, from the problem definition to the methodology" developing synergies; transdisciplinarity implies "is defined as the cooperation between scientists in academia, on one hand, and practitioners, decision makers or the public at large, on the other hand" (Barthel, \& Seidl, 2017, p. 4).

\section{Method}

This paper, based on the sociological perspective of the authors, seeks to contribute to the reflection on the relevance of a scientific project that aims to affirm an interdisciplinary perspective that may foster the heuristic potentialities of both Sociology and History in the analysis of the complexity of social reality and human action.

In order to achieve this goal, the privileged technique was the documentary analysis to collect information on the topic under study, developed from different types of documentary sources, with scientific articles being the main documentary source. The choice of the article as an empirical field of analysis results from considering that the article constitutes the central formal 
means of the scientific production and communication process, reporting on the scientific activity of scientists, where argumentative strategies of persuasion are developed and the interpretative principles privileged by the authors and legitimated by peers are presented.

The collection was based on the consultation of the B-ON database of the Foundation for Science and Technology (FCT) in Portugal, an electronic library resources, which includes databases of electronic scientific information such as the Web of Knowledge, DOAJ, SCIELO, and institutional repositories (Biblioteca do Conhecimento Online, n.d.). A search was carried out between 20 and 23 July, searching for the following words concomitantly in the title: "History" and "Sociology". This online bibliographic research was supplemented by the collection of complementary bibliographic material directly related to the topic under analysis.

\section{Sociology and History}

Sociology and History as consolidated scientific and academic projects have maintained a peculiar and paradoxical relationship (Turner, 2002). The growing disciplinary and subdisciplinary specialisation of these two sciences poses relevant epistemological and methodological challenges in order to face potential situations of isolation, fragmentation and enable the apology of an interdisciplinary perspective characterised by the historicity of social structures, actions and senses.

However, the codes of reading reality elaborated from the dominant paradigms in History and Sociology, although different, have often been, in these two disciplines, seen as non-interchangeable and incommunicable, promoting a "dialogue of the deaf", a "false dialogue", a polemic between a certain history and a certain sociology (Braudel, 1958a). This situation expresses crystallized positions in these disciplinary spaces. Sociological analysis would aim, through the verification of hypotheses, to identify in social phenomena what is uniform and likely to be repeated, to identify the existence of certain correlations between two series of phenomena. While historical analysis would aim to accumulate, through the examination of sources and the reconstitution of documents, significant data that allowed the understanding of a specific, unique and unrepeatable event (Ferrarotti, 1986). These positions enshrine a manifest contradiction between sociological analysis and historical research. Sociology would privilege a process of generalization, while History would be based on a process of individualization of the phenomenon (Ferraroti, 1986). 
However, Braudel distrusts a history that is limited to the exclusive account of events or successes, and distrusts a sociology that values an irreplaceable dimension of present time (1958b). In the Sociology Treatise published under Gurvitch's direction, this author defends the need to establish a dialogue and develop a greater collaboration between these sciences, which would initially go through a lexical unification. From the point of view of the historian, he sustains the preeminence of the historical levels - microhistory, cyclical history, structural history - over the sociological levels and, also, the preeminence of the time of history - a uniform time, general measure of the phenomena - over the multiform social time, particular measure of each of the phenomena, over the temporalities of Gurvitch (Braudel, 1958a; Mitrani, 1960).

The relationship between sociology and history has balanced the project, promoted by the exponents of positivism, of reducing the two disciplines to a single one (Ferrarotti, 1986), the emergence of Social History - a history that covered all human activities and was less associated with the narrative of events and more linked to the analysis of "structures" and encouraged collaboration with other social sciences -, the affirmation of Historical Sociology, focused on macroscopic, long-term, interdisciplinary historical research and imbued with a general interest in theoretical formulation (Turner, 2002, p. 280).

The processes of socialization, as an acquisition of culture that enables man to become a social being, are crucial for the formation, existence and change of societies (Ferreira \& Serpa, 2019). Society is also a transformation in time (Rocher, 1989). In this regard, Javeau (1998) argues that:

"Covering the interactions between individuals, the interactions between structures and between cultures weave the historical fabric on which our personal destinies are embroidered, most often at a very small point. Sociology studies at the same time the texture of the historical fabric and the tiny embroidery of our particular itineraries" (p. 213).

Since its beginnings, Sociology has also been interested in the historical dimension of apprehending social phenomena (Braga da Cruz, 1990; Javeau, 1998; Paiva, 2014; Rocher, 1989) as "studies the (dis)order of the social world, and that deals with interactions, what results from interaction and has implications in this interaction between human beings, such as objects, practices, representations and values, inserting them into their social context" (Serpa \& Ferreira, 2018, p. 841). Sociology's interest in the historical aspect of social phenomena is such that "it is possible to state that the first sociologists viewed social reality not as the photographer who would apprehend an immobilised moment outside time, but as the filmmaker who reconstitutes in 
the film the movement of beings and the course of events" (Rocher, 1989, p. 209).

This reality is present in countless sociological studies, even though, at times, history also exerts an influence on sociology. As some examples of the presence and influence of history in sociology, since the founding of sociology as a science, the philosophy of history, human and social evolution, and even history as a science can be indicated (Rocher, 1989). Here are just some classic examples of authors whose works reflect this influence. Max Weber, who developed studies, privileging a comparative historical analysis, on the commercial companies of the Middle Ages, the agrarian history of Rome, the Protestant ethics and the spirit of capitalism, the religions in the world; Norbert Elias, in his work Civilizational Process, sought to understand the process of evolution of civilizational patterns, especially in Europe, linked to the formation and individualization of European states; Immanuel Wallerstein, in world-systems theory analyzes the relationships of dependence and reciprocity between modern societies and nation-states; Fernand Braudel, developed a histoire globale in his work The Mediterranean and the Mediterranean World at the time of Filipe II (1949), linking history to other social sciences, articulating structures and events (Turner, 2002; Mandalios, 2002; Zubiría, 2015; Do Valle, 2014; Kirschner, 2014; Torres, 2012).

Zubiría (2015), Javeau (1998), Gould (2019) and Silva (2013), among many others, are some of the authors who consider that there is a very close relationship between Sociology and History. Javeau (1998) argues that History and Sociology "are but the two institutionalised facets of a single phenomenon (or combination of phenomena), collective life [...] there is no sociology that is not historical and there is certainly no history that is not sociological" (p. 202), this added to the fact that "it ponders the very conditions, historical-social, of sociological discourse production" (p. 207).

Philip Abrams' draft of a historical sociology emphasizes this position of integrating sociology and history, affirming that the only way to do sociology is historical. In terms of fundamental concerns, sociology and history are analogous, both seek to understand the challenges of human agency and both seek this goal in terms of the process of social structuring (Abrams, 1982). The conceptual emphasis on the process allows us to overcome the static-dynamic, structure-action, diachronic-synchronic dichotomies; the process can be seen as the connection between action and structure. This process is open, sequential and cumulative, at each stage the actions are undertaken from certain conditions and possibilities produced in the past which, in turn, 
transform the circumstances for the future (Table 1). Therefore, society can be understood as a historically constructed process by individuals who are historically constructed by society (Abrams, 1982; Sztompka, 1993).

Table 1: Dimensions and levels of a social process

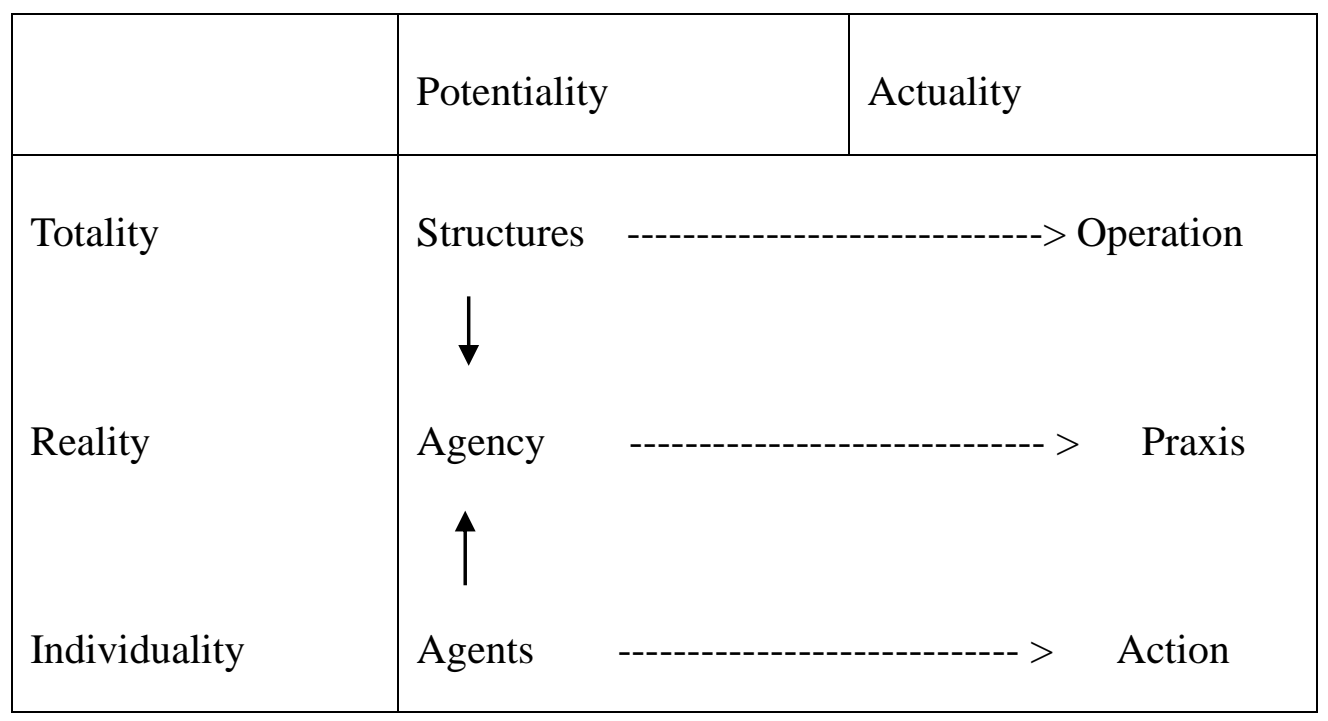

Source: Sztompka, 1993, p. 244.

On the other hand, Zubiría (2015) argues that "The dialogue between History and Sociology, as well as with other social sciences, is an ineludible epistemological, theoretical and methodological need and necessary for the advancement of scientific knowledge" (p. 264).

Since ideologies and practical knowledge are ways of rationalizing the world and classifying it, i.e., instruments of cohesion and social tension, all scientific disciplines are subject to the influence of symbolic-ideological elements (Silva, 1990). If ethnocentrism is presented as one of the main obstacles to the production of knowledge that is posed, in particular, to Sociology and Anthropology that to develop the epistemological rupture privileged the valuation of the analysis of the context; the anachronism is one of the main epistemological obstacles to History. But invoking the context to overcome anachronism may not be enough, given that the analysis of phenomena and actions in their socio-temporal context ends up having to face the difficulties that arise from the existence of different contexts (Rowland, 1987). Historians have developed different strategies to deal with the problem of difference in time, namely: that of not recognising any specific relevance to context and difference; that of considering that all the epochs analysed by the historian are different and irreducible to each other and that each one should be explained 
in its own terms - absolute respect for difference would end up excluding the possibility of any discourse about that same difference and the historian should abstain from any subjective interpretation of the meaning of those events; another strategy corresponds to a relativization of difference, in which the differences between epochs or societies are seen as the result of the internal differentiation of something broader whose specific characteristics allow us to relate societies or historical epochs to one another (Rowland, 1987, p. 1). 53-56).

An attitude of promotion of interdisciplinarity between sociology and history, of problematization of science and the mobilization of epistemological and methodological principles that guide social research can constitute a central strategy in overcoming the common sense with which the social sciences are debated and enhancing their heuristic capacities: relativization of human phenomena; appreciation of the socio-historical contexts and of the coordinates of time and place; relationship of social phenomena and inscription of these phenomena in systems of reciprocal relations, empirically verifiable; questioning and reflexive problematization of all the knowledge acquired, including common sense, ideologies and science itself (Rowland, 1987; Silva, 1990).

According to Augusto Santos Silva (2013), there is a need for a "sociologisation of history and a movement of historicisation of sociology" (p. 1).

However, what is the reason why this relationship between Sociology and History is not more fruitful? The constitution and institutionalization of scientific disciplines was, and is, a social process marked by ambivalence and indeterminacy in the (re)formulation of the respective identity (Charry Joya, 2017; Dayé, 2018; Serpa, Ferreira, \& Santos, 2017; Hernández Cordero, 2013; Gould, 2019; Steinmetz, 2017). Of the reasons for the separation between these two academic fields, factors such as scientific differences (epistemological and methodological) but also political factors, professional identity, the social space sought, the increase and maintenance of their autonomy, and the institutionalisation of the two scientific disciplines were relevant (Kirschner, 2014; Javeau, 1998; Charry Joya, 2017; Torres, 2012; Castillo Alonso, 2018), although an imperialist perspective of one of these disciplines over the other was no longer defended (Zubiría, 2015). According to Torres (2012), "interdisciplinarity was a discursive practice that developed together with the professionalization of knowledge" (p. 244). However, Steinmetz (2017) reminds us that "Interdisciplinarity is driven by three main sorts of motives, involving (1) questions that push scholars out of their own disciplines, (2) battles within a given discipline, and (3) conformity with internal or external authorities" (p. 481). 
"The historical sociologist is practiced at seeing beyond the details of particular events to focus on more general levels of analysis that are ripe for comparison. Historical sociology, in this way, may shepherd general sociology in the direction of general theory, in the direction of science" (Malczewski, 2019, p. 14).

In summary, it can be stated, in the wake of Silva (2013), that "what history problematizes is time, the inscription of societies in time, and this is the value it adds, as a "way of thinking" societies and, thus, as a way of thinking also the other social sciences" (p. 2).

\section{Conclusion}

There are several scientific reasons (epistemological and methodological), disciplinary closure, institutional reasons for maintaining a somewhat watertight separation, and social reasons for preserving professional identity, which explain this fluid movement of rapprochement/separation between Sociology and History, in what can be called contained dialogues. Do Valle presents an interesting perspective of this symbiotic relationship between Sociology and History, by considering that history, without the general concepts produced by sociology, would be reduced to a descriptive dimension, marked by a fictional sense, naïve in the relationship with what is described; on the other hand, sociology, without the particular phenomena made significant by cultural life, that is, without the historical phenomena, would tend to remain empty of content (Do Valle, 2014, p. 50). This interdisciplinary dialogue would make it possible to articulate in an interdependent way the understanding from within with the explanation from outside: the general with the singular, the heuristic sense for the structure of the sociologist with the heuristic sense of change, the social duration of the historian (Burke, 1980).

In this paper, based on the sociological perspective of its authors, we sought to contribute to the analysis of this connection that could potentially foster the heuristic capacity of both Sociology and History (Zubiría, 2015; Kirschner, 2014), seeking to demonstrate, from the studies analyzed, that the two scientific disciplines end up being interconnected and mutually nourishing.

The social structures and forms of social interaction that shape contemporary societies cannot be understood and explained without the mobilisation of a historical perspective, enhancing historicity, as opposed to naturalisation, of certain structures, actions and senses.

\section{Acknowledgements}

University of Azores, Interdisciplinary Centre of Social Sciences-CICS.UAc/CICS.NOVA.UAc, 
UID/SOC/04647/2019, with the financial support of the FCT/MEC through national funds and when applicable co-financing from the FEDER under the PT2020 Partnership Agreement.

\section{References}

Abrams, P. (1982). Historical Sociology. Ithaca: Cornell University Press

Baechler, J. (1990). História e sociologia. In R. Boudon, P. Besnard, M. Cherkaoui, \& B.-P. Lécuyer (Dirs.), Dicionário de sociologia [Dictionary of sociology] (pp. 120 and 121). Lisboa: Publicações Dom Quixote.

Biblioteca do Conhecimento Online (n.d.). What is b-on? [Online]. Available at https://www.b-on.pt/en/what-is-b-on/.

Braga da Cruz, M. (1989). Teorias sociológicas. Os fundadores e os clássicos (Antologia de textos) (I Vol.). Emile Durkheim [Sociological theories. The founders and the classics (Anthology of texts) (I Vol.). Emile Durkheim]. Lisboa: Fundação Calouste Gulbenkian.

Braudel, F. (1958a). Histoire et Sociologie. in Gurvitch, G. (dir.). Traité de Sociologie. Paris: Presses Universitaires de France

Braudel, F. (1958b). Histoire et sciences sociales: «la longue durée», Annales E.S.C., n. ${ }^{\text {4 }}$, Oct.-Dec., Débats et Combats, 725-753

Burke, P. (1980). Sociology and History. London: George Allen \& Unwin

Castillo Alonso, J. J. (2018). Para una autoetnografía intelectual: Sociología, historia, trabajo de campo... [For an intellectual autoethnography: Sociology, history, field work...]. Sociología del Trabajo, 0(92), 7-31. doi: 10.5209/stra.59577.

Charry Joya, C. A. (2017). Tan cerca y tan lejos. Los problemas disciplinares entre sociología e historia y la práctica de una nueva sociología histórica [So close and yet so far. The disciplinary problems between sociology and history and the practice of a new historical sociology]. Revista de Estudios Sociales, 35(60), 36-48. doi: 10.7440/res60.2017.03.

Dayé, C. (2018). A systematic view on the use of history for current debates in Sociology, and on the potential and problems of a historical epistemology of Sociology. The American Sociologist, 49(4), 520-547. doi: 10.1007/s12108-018-9385-1.

Do Valle, U. (2014). A relação entre História e Sociologia no horizonte da conceitualização e da explicação dos objetos históricos: reflexões sobre o pensamento de Max Weber [The relationship between History and Sociology over the horizon of conceptualization of Max Weber]. História e Cultura, 3(3), 28. doi: 10.18223/hiscult.v3i3.1408.

Dubar, C. (2006), Le pluralisme en sociologie: Fondements, limites, enjeu [Pluralism in sociology: Foundations, limits, stakes].Socio-Logos, 1. Available online: http://socio-logos.revues.org/20(accessed on 29 March 2008).

Gould, M. (2019). History is Sociology: All arguments are counterfactuals. Journal of Historical Sociology, 32(1), e1-e10. doi: 10.1111/johs.12230.

Ferguson, S. J. (2016). The Center Does Hold: The Sociological Literacy Framework. Teaching Sociology. Vol. 44(3) 163-176. https://doi.org/10.1177/0092055x16651478

Ferreira, C. M., \& Serpa, S. (2017). Challenges in the teaching of Sociology in higher education. Contributions to a discussion. Societies, 7, 30. doi: 10.3390/soc7040030.

Ferreira, C. M., \& Serpa, S. (2019). Socialization: A key concept in social sciences. In Proceedings of SOCIOINT 2019 - $6^{\text {th }}$ International Conference on Education, Social Sciences and Humanities. Istanbul, Turkey, June 24-26. ISBN: 978-605-82433-6-1 691.

Ferrarotti, F. (1986). Sociologia. Lisboa: Teorema

Hernández Cordero, Y. (2013). La Historia y su relación con otras ciencias. Sociología y Antropología [History and its relationship with other sciences. Sociology and Anthropology]. Ra Ximhai, 145-150. doi: 10.35197/rx.09.02.e.2013.10.yh.

Javeau, C. (1998). Lições de sociologia [Lessons of sociology]. Oeiras: Celta Editora.

Kirschner, T. C. (2014). História e Sociologia: A contribuição de Norbert Elias [History and Sociology: The 
contribution of Norbert Elias]. História e Cultura, 3(3), 53. doi: 10.18223/hiscult.v3i3.1409.

Mandalios, J. (2002). Sociologia Histórica. In Turner, B. (ed.). Teoria Social. Algés: Difel, 283- 308

Mitrani, N. (1960). Gurvitch G. (dir.), Traité de Sociologie (compte-rendu). Revue Française de Sociologie, Année $1960,1-1,105-108$

Morrison, A. (2017). A sociologist teaches history: Some epistemological and pedagogical reflections. Educ. Stud., 53, 233-246.

Paiva, A. (2014). Pensamento sociológico. Uma introdução didática às teorias clássicas [Sociological thought. A didactic introduction to classical theories]. Lisboa: PACTOR: Edições de Ciências Sociais, Forenses e da Educação.

Rocher, G. (1989). Sociologia Geral. A organização geral (Vol. 2) [General Sociology. The general organization (Vol. 2)]. Lisboa: Editorial Presença.

Rowland, R. (1987). Antropologia, História e Diferença. Porto: Edições Afrontamento

Serpa, S., \& Ferreira, C. M. (2018). Sociological problem and social problem: Contributions to a discussion. Sociology and Anthropology, 6(11), 840-844. doi: 10.13189/sa.2018.061104.

Serpa, S., Ferreira, C. M., \& Santos, A. I. (2017). Fostering interdisciplinarity: Implications for social sciences. International Journal of Social Science Studies, 5(12), 44. doi: 10.11114/ijsss.v5i12.2775.

Sethuraju, N.; Prew, P.; Abdi, A.; Pipkins, M. (2013). The consequences of teaching critical sociology on course evaluations. SAGE Open, 1-15.

Silva, A. S. (2013). Processos no tempo: Uma reflexão sobre o valor que a história acrescenta à sociologia, a partir do magistério de Vitorino Magalhães Godinho [Processes in time: A reflection on the value that history adds to sociology, based on the teaching of Vitorino Magalhães Godinho]. Forum Sociológico, (23). doi: 10.4000/sociologico.848.

Silva, A. S., \& Pinto, J-. M. (1986). Uma visão global sobre as ciências sociais [A global view on social sciences]. In A. S. Silva, \& J. M. Pinto (Orgs.), Metodologia das ciências sociais [Methodology of social sciences] (pp. 9-27). Porto: Edições Afrontamento.

Silva, A. (1990). A ruptura com o senso comum nas ciências sociais. In Silva, A. \& Pinto, J. (Orgs.), Metodologia das Ciências Sociais. Porto: Edições Afrontamento, 29-53

Steinmetz, G. (2017). Field Theory and interdisciplinarity: History and Sociology in Germany and France during the twentieth century. Comparative Studies in Society and History, 59(2), 477-514. doi: 10.1017/s0010417517000111.

Sztompka, P. (1993). Sociología del cambio social. Madrid: Alianza Editorial

Torres, D. R. V. (2012). Sobre historia y sociologia: interdisciplinariedad y narracion en las ciencias sociales en Colombia [On history and sociology: Interdisciplinarity and narration in the social sciences in Colombia]. Anuario Colombiano de Historia Social y de la Cultura, 39(1), 243-262.

Turner, B. (ed.) (2002). Teoria Social. Algés: Difel

Zubiría, B. (2015). Convergencias y divergencias entre Sociología e Historia [Convergences and divergences between Sociology and History]. Historia Caribe, X(27), 231-268. doi: 10.15648/hc.27.2015.8. 